\title{
EOCAMBRIAN PALEOMAGNETISM OF THE BOSTON BASIN: EVIDENCE FOR DISPLACED TERRANE
}

Fang Wu, Rob Van der Voo, and Rex J. E. Johnson

Department of Geological Sciences, University of Michigan, Ann Arbor, MI. 48109

Abstract. A paleomagnetic study of the Late Precambrian Roxbury formation, consisting of extrusives and clastic sediments, has yielded a steeply downward directed and pre-folding characteristic magnetization $\left(D / I=219^{\circ} / 71^{\circ}, \alpha 95=5^{\circ}\right.$, k $=311$, paleopole at $13^{\circ} \mathrm{N}, 267^{\circ} \mathrm{E}, \mathbf{N}=4$ sites), which indicates a significantly higher paleolatitude $\left(55^{\circ}\right)$ than would be expected if the Boston basin were part of the equatorial North American craton in the latest Precambrian and earliest Paleozoic. This characteristic magnetization reveals dual polarities and is further supported by a positive conglomerate test. A ubiquitous post-folding late Paleozoic overprint is present in nine sites $\left(D / I=183^{\circ} / 14^{\circ}, \alpha 95=8^{\circ}, \mathrm{k}=42\right)$, with a paleopole at $41^{\circ} \mathrm{S}, 285^{\circ} \mathrm{E}$. The pre-folding magnetization resides in hematite, which is inferred to have formed during early oxidation of the rocks; the high stability of this hematite may have prevented its magnetization from being reset during the late Paleozoic chemical event responsible for the magnetic overprint. The Boston basin has a marked geological similarity to the Avalon basement terranes in Nova Scotia and Newfoundland, as well as the Armorican Massif in France, and the high paleolatitudes observed for all these terranes suggest a common paleogeographical affinity; a likely paleolocation is near the northwestern margin of Gondwana which was located at the southpole in the latest Precambrian and Early Cambrian.

\section{Introduction}

The Boston basin and much of eastern Massachusetts form part of the Avalon zone in the Appalachians, and there is now a general consensus that the Avalon terranes may be exotic (Wilson, 1966; williams and Hatcher, 1983). They are thought to have joined the North American craton during the Devonian or Carboniferous as a result of the closing of the Iapetus ocean. In order to test and quantify the displacement hypothesis for these terranes, paleomagnetic studies of latest Precambrian and early Paleozoic rocks were initiated. Several results have already been published for 'Cape Breton Island in Nova Scotia (Johnson and Van der Voo, 1985, 1986; Van der Voo and Johnson, 1985). Coupled with previous paleomagnetic work (Schutts et al., 1976; Hurley and Shearer, 1981; Kent, 1982; Irving and strong, 1985; Weisse et al., 1985) a picture is emerging that confirms the exotic nature of the Avalon terranes. However, some questions still remain to be answered. For instance, did the terranes join North America at the same time or did they arrive as individually accreted terranes at different times? Where did the terranes originate? This

Copyright 1986 by the American Geophysical Union.

Paper number 6L6393.

$0094-8276 / 86 / 006 \mathrm{~L}-6393 \$ 03.00$ study addresses the last question, in so far as the Boston basin is concerned.

Geology, Sampling and Laboratory Measurements

Figure 1 shows the general geology of the basin, based on previous geological work (La Forge, 1932; Billings, 1929, 1976, 1980, 1982; Pollard, 1965; Cameron, 1979; Lenk et al., 1982; Kaye, 1984). The basin, bounded on three sides by faults and by Boston Bay in the east, consists of the Dedham granite as a widespread basement rock overlain by the Mattapan volcanic complex and the volcano-sedimentary Boston Bay group. The Dedham granite has yielded an age of $630 \pm 15$ Ma with the U-Th-Pb zircon method and volcani $\overline{c s}$ of the Mattapan complex gave a zircon age of 603 $+3 \mathrm{Ma}$ (Kaye and zartman, 1980). Contact relationships between these volcanics and the granite are complex: in some places the volcanics overlie the granite, elsewhere the granite appears to intrude them. The Boston Bay group, however, clearly rests on the Dedham granite and the Mattapan complex, and it is constrained in age by the above-mentioned radiometric dates and the occurrence of an Eocambrian microflora in its upper part, which correlates with fossils from localities in Greenland, Norway and central U.S.S.R. (Lenk et al., 1982; Kaye; 1984).

The Boston Bay group is divided into two formations, the Roxbury conglomerate and the younger Cambridge argillite, separated by the squantum "tillites", a unique conglomeratic stratum of up to $120 \mathrm{~m}$ in thickness but controversial because of the long debate over its glacial origin (Cameron, 1979). Structural analysis is hampered by a lack of exposures, so that it is not clear whether the overlying Cambrian formations are in conformable contact (Kaye and Zartman, 1980) or in fault contact (Billings, 1982) by the Blue Hill thrust (BHT in Figure 1). Folding in the area occurred during the Permo-Carboniferous Alleghenian orogeny, although folding and faulting during an Avalonian event at the PrecambrianCambrian boundary is likely as well. Folds are large with gently dipping limbs and the east-west striking fold axes that we could observe have a plunge of $15^{\circ}-20^{\circ}$ to the east. Consequently, the older rocks are generally exposed in the southwest. Metamorphism is of very low grade, though hydrothermal alteration has produced secondary chlorite, epidote and kaolinite.

Sampling, with a portable drilling apparatus in 1983, of 13 sites in the stratified volcanics and red siltstones of the Roxbury formation was designed to select sites with fresh rocks and unambiguous structural control. The Natural Remanent Magnetizations (NRM's) were measured with a cryogenic magnetometer or a schonstedt spinner magnetometer; thermal or alternating field demagnetizations were performed with Schonstedt equipment. Chemical demagnetization on selected pilot samples showed that satisfactory isolation of 


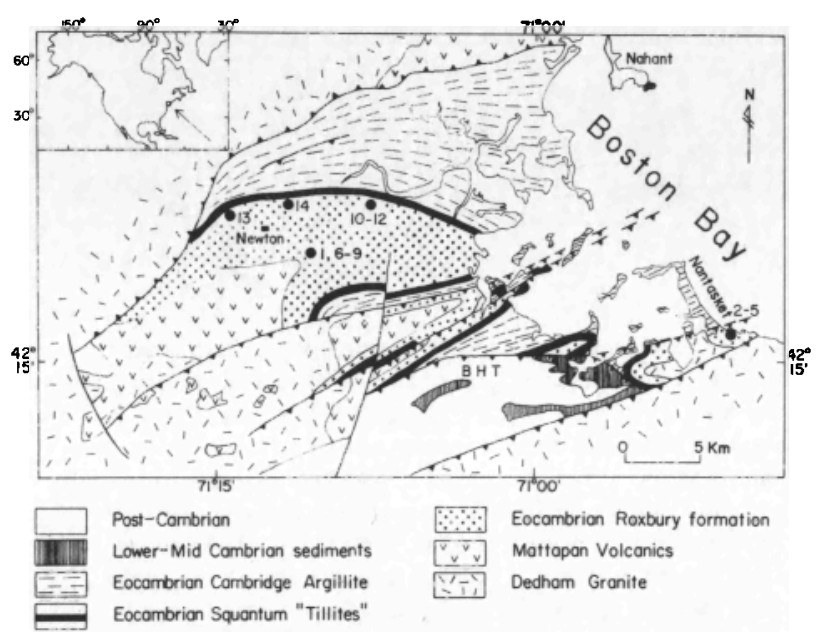

F1g. 1. Geological sketch map of the Boston Basin (after Billings, 1976). BHT is the Blue Hills thrust. Solid dots with numbers identify the sampling sites.

magnetization components was not achieved, so this technique was not continued. Demagnetization results were analyzed by plotting orthogonal diagrams (Zijderveld, 1967), great-circle analysis (Halls, 1976), and the vector difference method of Hoffman and Day (1978). The bedding corrections included a correction for the plunge of the folds, which results in minor declination changes of up to $3^{\circ}$ (see details in Fang Wu, 1984).

\section{Paleomagnetic Results}

NRM and Demagnetization Behavior

NRM intensities varied between $10^{-1}$ and $10^{-3}$ $\mathrm{A} / \mathrm{m}$, with NRM directions generally steeply down (Fang Wu, 1984). Stepwise demagnetization revealed univectorial magnetizations with moderate to steep inclinations in a few cases (Figure 2a). but more typically the orthogonal plots displayed two or more components (Figure 2b). In samples w1th discrete high blocking temperature magnetizations $\left(670\right.$ to $680^{\circ} \mathrm{C}$ in Figure $\left.2 \mathrm{~b}\right)$, it appears that a component could be isolated with a direction identical or antiparallel to those of the univectorial magnetizations. These are called the characteristic components in this paper and are plotted with the site means in Figure 3 (see also Table 1).

As is frequently the case in paleomagnetic studies of clastic sediments and some volcanics. a low-coercivity or low blocking-temperature component with a northerly and steeply down direction is first removed in the demagnetization process (Figure $2 \mathrm{~b}, \mathrm{c}$ : below $660^{\circ} \mathrm{C}$ ). This component conforms to the direction of the present geomagnetic field in Boston and is inferred to be of recent origin.

A southerly and shallow component is seen in many samples, often without the characteristic component (Figure 2c), but occasionally the shallow component is seen as a lower-temperature overprint on the characteristic component (Figure 2d). In these samples non-discrete blocking temperatures, curved demagnetization trajectories and apparently overlapping blocking temperature spectra are often observed (Figure 2d). Directions from samples with such curved trajectories were analyzed with great-circle techniques, but without much success: because the great circles were largely parallel, no well-defined intersection could be determined. Consequently, where suspicions existed about overlapping blocking temperature spectra, no directions were included in the final means. The directions of the shallow and southerly components which did not overlap significantly with the characteristic components are given as site-means in Table 1.

Tests for the Ages of the Magnetizations

A fold test, a conglomerate test and a bakedcontact test were attempted to constrain the age of magnetization. As can be seen in Figure 3, the site-mean directions for the characteristic magnetization cluster much better after correction for the tilt of the strata and the moderate plunge of the fold axis. The statistical values associated with this fold test indicate that it is positive and significant at the $95 \%$ confidence level for the characteristic magnetization, with
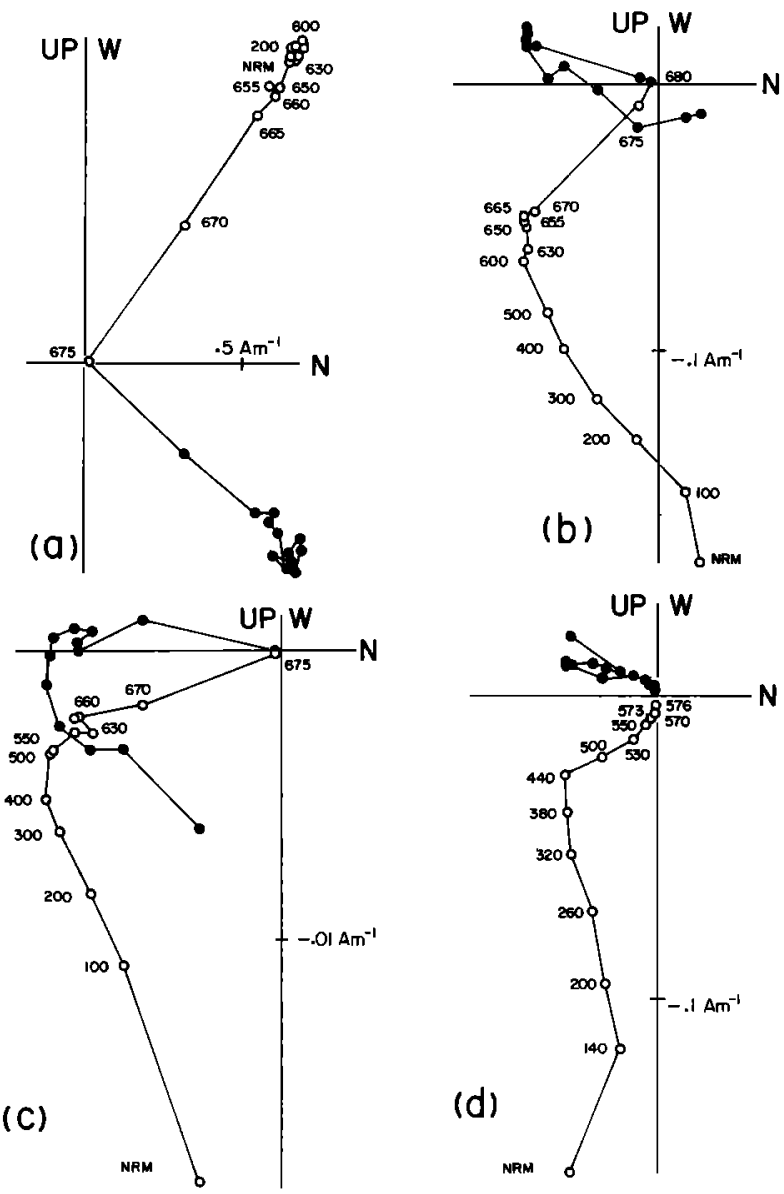

Fig. 2. Orthogonal vector diagrams (zijderveld, 1967) of representative samples, without correction for the tilt of the strata. Solid (open) symbols represent projections onto the horizontal (vertical) plane. Numbers denote temperatures $\left({ }^{\circ} \mathrm{C}\right)$ during thermal demagnetization. (a) volcanic sample from site 6 showing a univectorial characteristic direction. (b) red siltstone from site 6 showing the characteristic magnetization at high temperatures. (c) red siltstone (site 1), showing the Permian overprint at higher temperatures. (d) volcanic sample from site 5 showing overlapping blockıng temperature spectra for the Permian overprint and the characteristic component. 
TABIE 1. Summary of Paleomagnetic Results

\begin{tabular}{|c|c|c|c|c|c|c|}
\hline site & $\begin{array}{l}\text { Rock } \\
\text { type }\end{array}$ & $n / N$ & $\begin{array}{l}\text { Before T.C. } \\
\text { Decl./Incl. }\end{array}$ & $\begin{array}{l}\text { After T.C.. } \\
\text { Decl./Incl. }\end{array}$ & $\mathbf{k}$ & $\alpha=$ \\
\hline \multicolumn{7}{|c|}{ Permian Overprint } \\
\hline 1 & $\mathbf{s}$ & $3 / 8$ & $172.1 /+15.4$ & $169.9 /+3.0$ & 54 & \\
\hline 2 & $\mathrm{~V}$ & $2 / 8$ & $179.4 /+9.0$ & $177.4 /-3.6$ & - & \\
\hline 3 & V & $6 / 11$ & $200.0 /+19.9$ & $195.1 /+10.7$ & 8 & \\
\hline 4 & v & $5 / 6$ & $179.6 /+16.2$ & $174.0 /-1.3$ & 49 & \\
\hline 5 & $\mathrm{v}$ & $2 / 8$ & $202.6 /+20.0$ & $198.9 /+6.9$ & - & \\
\hline 6 & s, & $2 / 14$ & $169.8 /+18.2$ & $165.8 /+35.0$ & - & \\
\hline 7 & $\mathbf{s}$ & $3 / 6$ & $177.7 /+7.3$ & $177.3 /+25.9$ & 40 & \\
\hline 8 & $\mathbf{s}$ & \multicolumn{5}{|c|}{ Conglomerate test, } \\
\hline 10 & v & $3 / 18$ & $184.1 /+1.4$ & $181 \cdot 2 /+28.5$ & 37 & \\
\hline 11 & $\mathrm{~V}$ & $2 / 2$ & $182.4 /+14.3$ & $179.4 /+40.8$ & - & \\
\hline 13 & $\mathbf{s}$ & \multirow{2}{*}{\multicolumn{5}{|c|}{ overlapping blocking temperatures }} \\
\hline 14 & v & & & ations & & \\
\hline
\end{tabular}

\begin{tabular}{rccccrrr}
\multicolumn{8}{c}{ Characteristic Direction } \\
6 & S,V & $12 / 14$ & $214.5 /+51.3$ & $227.5 /+71.6$ & 131 & 4 \\
9 & S & $9 / 9$ & $184.0 /+41.4$ & $217.5 /+70.9$ & 62 & 7 \\
10 & V & $5 / 18$ & $208.9 /+36.3$ & $216.9 /+65.2$ & 22 & 17 \\
12 & S & $3 / 4$ & $205.8 /+46.2$ & $212.4 /+75.2$ & 62 & 16 \\
Mean**S,V & $4 / 13$ & $202.9 /+44.4$ & $218.7 /+70.8$ & 311 & 5 \\
\hline
\end{tabular}

$\mathrm{n} / \mathrm{N} \equiv$ number of samples or sites used to compute the mean, versus the number of samples (sites) demagnetized; T.C. = tectonic correction; $S=$ sediments, $v=$ volcanics; *, mean with the precision parameter $(k)$ and cone of confidence $(\alpha 95)$ for the case before and $\star *$, after tectonic correction.

the precision parameters after $(k 2)$ and before unfolding (kl) giving a ratio $(k 2 / k 1)$ of 6.31 . on the other hand, the shallow and southerly directions fail the fold test $(k 2 / k 1=0.41)$, and are therefore of post-folding age. Since all (or at least a major part) of the folding was of Late Carboniferous-Early Permian age, this implies that the characteristic magnetization is older than the Late Carboniferous and that the shallow southerly magnetization is of Late Paleozoic or younger age.

Site 8 was sampled in a conglomerate just above sites 6 and 7 . Some of the cobbles were derived from the Mattapan volcanics and they revealed random directions of magnetization with distributed blocking temperatures and univectorial demagnetization diagrams (Fang Wu, 1984, his fig.9). This suggests that these magnetizations predate the deposition of the cobbles and that some of the Eocambrian rocks escaped remagnetization after their deposition. Moreover, since some of the cobble magnetizations clearly

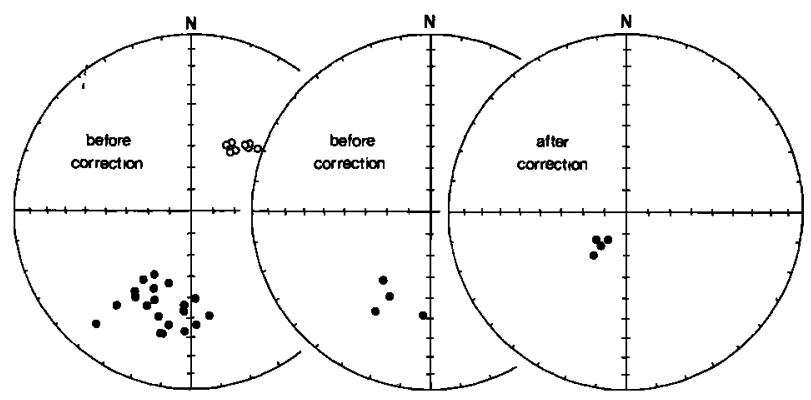

Fig. 3. Equal area projections of the characteristic directions of magnetization for samples (left) and site means (right). Closed (open) symbols are in the lower (upper) hemisphere.

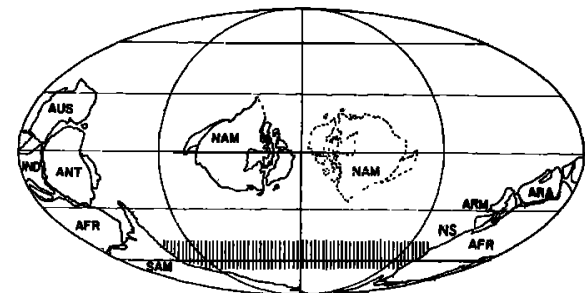

Fig. 4. Eocambrian paleogeographic map, with North America shown in solid and in dashed lines: these two positions represent alternatives on the basis of normal versus reversed polarity paleopoles. NS $=$ Nova Scotia's Avalon terrane, ARM = Armorica, other continents are identified by their first three letters. The shaded zone indicates the most likely position(s) of the Boston Basin area as suggested by this study.

reside in hematite, this mineral is inferred to have a very early origin. The remagnetizations that were observed are thus more likely to be of chemical than of thermal origin, and the more impermeable volcanic rock types could more readily escape the fluid reactions that reset the sediments.

Site 10 contained several large siltstone xenoliths in basalt. Most of these baked siltstones revealed only the northerly magnetization of recent origin, but two specimens showed the same characteristic component as the basalt. This test cannot be called conclusive for lack of statistical weight, but it is supportive of an early origin for the characteristic magnetization.

Lastly, we can compare the directions of magnetization with those obtained for other North American rocks. The shallow and southerly postfolding magnetization gives a paleopole $\left(40.7^{\circ} \mathrm{N}\right.$, $105.1^{\circ} \mathrm{E}$ ) which falls near the Permian segment of the North American polar wander path, whereas the characteristic magnetization is much steeper than, and quite different from, any latest Precambrian or younger magnetizations for the craton. The paleopole is located at $13^{\circ} \mathrm{N}, 267^{\circ} \mathrm{E}$, dp $=7.8^{\circ}$ and $d m=9.0^{\circ}$. We argue that it is safe to conclude that the characteristic magnetization is not representative of the known paleomagnetic field for North America, though it cannot be precluded that it represents a (pre-Late Devonian) remagnetization during the time that the Boston Basin was not yet part of North America.

In summary of this section, we argue that the age of the characteristic magnetization is preLate Devonian and possibly latest Precambrian in age, whereas the shallow and southerly overprint is of Permian age.

\section{Discussion}

The characteristic direction, though indicated by the demagnetizations as present in most sites, could only be defined precisely in four sites (Table 1), because of overlapping blocking-temperature spectra. Nevertheless, we believe that secular variation has been averaged out in the mean, because of the individual entries for sediments as well as extrusives, and that the mean is representative of the ancient field at the time of magnetization acquisition. This characteristic magnetization does not resemble any known paleomagnetic field for North America for Phanerozoic time, as already mentioned. This is our main evidence for concluding that the Boston basin was 
indeed an exotic or displaced terrane, as had been hypothesized earlier (e.g., Wilson, 1966; Skehan and Rast, 1976; williams and Hatcher, 1983; Zen, 1983). Similar conclusions have been reached on the basis of Cambrian and Ordovician paleomagnetic results for the Avalonian basement of Nova Scotia (Johnson and Van der Voo, 1985, 1986; Van der Voo and Johnson, 1985).

In a more speculative mode we can attempt to compare our result with those for other continents, under the assumption that the characteristic magnetization of the Roxbury is of latest Precambrian age. Figure 4 gives a paleogeographic reconstruction for that time, with a paleolatitude band around $55^{\circ} \mathrm{S}$ shaded to indicate the likely position(s) for the Boston basin area. If our choice for a southerly (rather than a northerly) paleolatitude position is correct, it can be seen that a position off the coast of northwest Africa is supported by the new paleomagnetic data, in agreement with previous postulates on the basis of geological correlations (Cameron, 1979). A similar, but slightly more northerly position is indicated for the Avalon terrane of Nova Scotia (Johnson and Van der Voo, 1986) and for Armorica (Perigo et al., 1983), as shown in Figure 4.

Acknowledgments. C. A. Kaye and M. D. Thompson provided valuable help in organizing the field work and we thank them, as well as Carola Stearns and valerian Bachtadse for their suggestions during the course of this study. This study was supported by grant 3259-84 of the Geological Society of America, by the Scott Turner Fund of the University of Michigan and by the National Science Foundation, Division of Earth Sciences, grant 84-07007.

\section{References}

Billings, M. P., Structural geology of the eastern part of the Boston Basin, Amer. J. Sci., 18, 97-137, 1929.

Billings, M. P., Geology of the Boston Basin, Geol. Soc. Amer. Mem., 146, 5-30, 1976.

Billings, M. P., Boston Basin, Massachusetts, U.S. Geol. Surv. Prof. Paper, 1110A, A51-A120, $1 \overline{980}$.

Billings, M. P., Ordovician cauldron subsidence of the Blue Hills Complex, eastern Massachusetts, Geol. Soc. Amer. Bull., 93, 909-920, 1982.

Cameron, B., Evidence for glaciation in the Boston Basin, in Carboniferous basins of SE New England, Field Trip Guidebook, 5 , edited by B. Cameron, pp. 75-80, 9th Intern. Congr. Carb. Stratigr. and Geol., Amer. Geol. Inst., Falls Church, Virginia, 1979.

Fang Wu, Paleomagnetism of the Eocambrian Roxbury Formation, Boston Basin, Massachusetts, M.Sc. thesis, University of Michigan, 44 pp., 1984.

Halls, H. C., A least-squares method to find a remanence direction from converging remagnetization circles, Geophys. J. Roy. astr. Soc., $45,297-304,1976$.

Hof $\overline{f m a n}$, K. A., and Day, R., Separation of multicomponent NRM: a general method, Earth Planet. Sci. Lett.., 40, 433-438, 1978.

Hurley, P. M., and shearer, C. K., Paleomagnetic investigations in igneous-metamorphic rock units in eastern New England, Can. J. Earth Sci., 18, 1248-1260, 1981.

Irving, E., and Strong, D. F., Paleomagnetism of rocks from the Burin peninsula, Newfoundland: hypothesis of Late Devonian displacement of Acadia criticized, J. Geophys. Res., 90, 1949$1962,1985$.
Johnson, R. J. E., and Van der Voo, R., Middle Cambrian paleomagnetism of the Avalon terrane in Cape Breton Island, Nova Scotia, Tectonics, 4, 629-651, 1985 .

Johñson, R. J. E., and Van der Voo, R., Paleomagnetism of the Late Precambrian Fourchu Group, Cape Breton Island, Nova Scotia, Can. J. Earth Sci.., in press, 1986.

Kaye, C. A., Boston Basin restudied, in Geology of the coastal lowlands, Boston to Kennebunk, ME, edited by L. S. Hanson, Pp. 124-144, 76th Ann. New England Intercoll. Geol. Conf., B2, 1984.

Kaye, C. A., and Zartman, R. E., A late Proterozoic to Cambrian age for the stratified rocks of the Boston Basin, MA, in The Caledonides of the U.S.A., edited by D. R. Wones, pp. 257-262, IGCP Project 27, Virginia Polytechn. Inst. and State Univ., Memoir, 2, 1980.

Kent, D. V., Paleomagnetic evidence for postDevonian displacement of the Avalon platform (Newfoundland), J. Geophys. Res., 87, 8709$8716,1982$.

La Forge, A., Geology of the Boston area, MA, U.S. Geol. Surv. Bull., 839, 105 pp., 1932.

Lenk, C., Strither, P. K., Kaye, C. A., and Barghoorn, E. S., Precambrian age of the Boston Basin: new evidence from microfossils, Science, $216,619-620,1982$.

Perigo, R., Van der Voo, R., Auvray, B., and Bonhommet, N., Paleomagnetism of Late Precambrian-Cambrian volcanics and intrusives of the Armorican Massif, Geophys. J. Roy. astr. Soc., $75,235-260,1983$.

Pollard, M., Age, origin and structure of postCambrian Boston strata, MA, Geol. Soc. Amer. Bull., 76, 1065-1068, 1965.

Schutts, L. D., Brecher, A., Hurley, P. M., and Montgomery, C. W., A case study of the time and nature of paleomagnetic resetting in a mafic complex in New England, Can. J. Earth Sci., 13, 898-907, 1976.

Skehan, J. W., and Rast, N., Paleozoic margins of paleo-American and paleo-Eurafrican plates, drifting and rifting, Geology, 4, 185-186, 1976.

Van der Voo, R., and Johnson, R. J. E., Paleomagnetism of the Dunn Point Formation (Nova Scotia): high paleolatitudes for the Avalon terrane in the Late Ordovician, Geophys. Res. Lett., 12, 337-340, 1985.

Weisse, P. A., Haggerty, S. E., and Brown, L. L., Paleomagnetism and magnetic mineralogy of the Nahant gabbro and tonalite, eastern Massachusetts, Can. J. Earth Sci.., 22, 1425-1435, 1985.

williams, H., and Hatcher, R. D., suspect terranes: a new look at the Appalachian orogen, Geol. Soc. Amer. Mem., 158, 33-53, 1983.

Wilson, J. T., Did the Atlantic close and then reopen ? Nature, 211, 676-681, 1966.

Zen, E-An, Exotic terranes in the New England Appalachians - limits, candidates, and ages: a speculative essay, Geol. Soc. Amer. Mem., 158, $55-81,1983$.

Zijderveld, J. D. A., A.C. demagnetization of rocks: analysis of results, in Methods in Paleomagnetism, edited by $D . W$. Collinson, $K$. M. Creer and S. K. Runcorn, pp. 254-286, Elsevier, Amsterdam, 1967.

Fang Wu, Rob Van der Voo and Rex J. E. Johnson, Department of Geological Sciences, the University of Michigan, Ann Arbor, MI. 48109-1063, U.S.A.

(Received October 2, 1986; accepted november $3,1986$. ) 